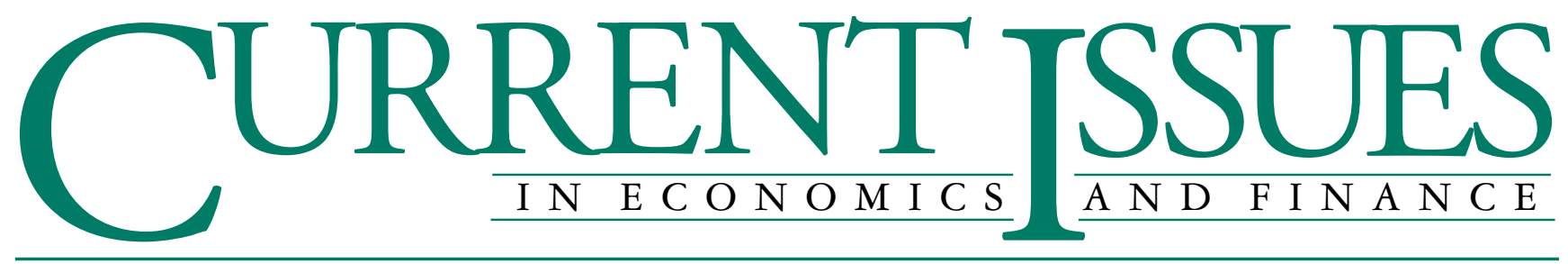

November 1999

Volume 5 Number 15

\title{
Credit Risk in Japan's Corporate Bond Market
}

Frank Packer

From the fall of 1997 to the spring of 1999, yield spreads in Japan's corporate bond market increased sharply. An analysis of this rapid rise suggests that Japanese investors in corporate bonds may be paying closer attention to the credit risk of individual issuers. Such a shift in investor focus would represent a major change in the structure of this market.

In recent years, Japan's major corporations have increasingly relied on the corporate bond market as a source of debt finance. From 1996 to 1998, the issuance of corporate bonds increased more than 46 percent, from 30.8 trillion yen to about 45 trillion yen (Table 1). ${ }^{1}$ At the same time, loans from Japan's banking sector decreased about 17 trillion yen. As the corporate bond market grew, the spreads between the yields on Japanese corporate and government bonds widened dramatically.

In this edition of Current Issues, we investigate the reasons for the pronounced increase in spreads in Japan's corporate bond market. We first consider the effect of weak macroeconomic conditions on spreads. Slowed economic growth, increased bankruptcies, and financial market turbulence helped bring about a decline in the credit quality of Japan's outstanding bond issues. With lower credit ratings suggesting an increased likelihood of future defaults, the spreads between the yields on corporate bonds and government bonds widened.

Economic and financial conditions, however, cannot fully account for the rise in spreads. Structural changes in the Japanese bond market also appear to have contributed to the increase in spreads. We uncover two developments that support this view. First, bond yields have become increasingly correlated with credit ratings, a key measure of credit risk, over the past few years. This change suggests that credit risk-historically a minor factor in the pricing of Japan's corporate bondsis a much greater concern among Japanese investors than in the past.

Second, yield spreads have increased the most among firms that belong to a keiretsu - an informal network of large firms that maintain close business, financial, and managerial ties. In the past, keiretsu members facing the threat of bankruptcy could count on financial backing from the group's main bank. ${ }^{2}$ The disproportionately large increase in spreads among keiretsu firms, however, indicates that investors may perceive membership in a keiretsu as less of a safeguard against default than in the past.

\section{Macroeconomic Conditions and the Downward Trend in Credit Quality}

In the fall of 1997, economic conditions deteriorated markedly in Japan. Real growth turned negative, and remained negative through the fourth quarter of 1998. The failure of several major financial institutions led to increased concern about the stability of Japan's financial system (Miyanoya 1998). In the course of Japan's economic troubles, the number and scale of corporate bankruptcies increased rapidly: In fiscal year 1997, the 


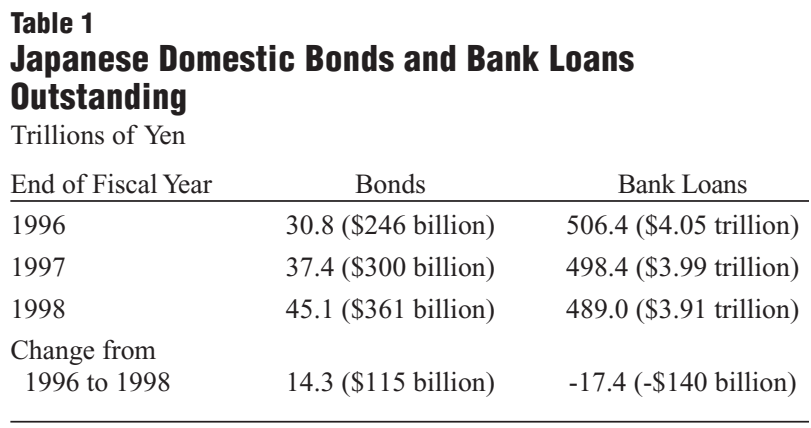

Sources: Bank of Japan; Nikkei Telecom.

Notes: Outstanding bonds do not include convertible bonds. Loans are of domestically licensed banks and include discounted bills, as well as trust account loans and discounts. The exchange rate used for the calculation of dollar figures is the average rate from April 1997 through March 1999, or 125 yen = 1 dollar.

liabilities of firms claiming bankruptcy increased from 9.3 trillion yen to 12.6 trillion yen. In the following year, that figure rose to 15.1 trillion yen. ${ }^{3}$

Credit rating agencies responded to the decline in economic conditions by downgrading many Japanese corporate issuers. In October 1997, 15.1 percent of Japanese corporate issuers with U.S. agency ratings had high credit marks of AAA or AA. ${ }^{4}$ By April 1999, the share of high-rated issuers had declined to 10.6 percent (Chart 1). In addition, the share of companies rated non-investment-grade by U.S. agencies (an average rating of $\mathrm{BB}+$ or less) increased from roughly 21 percent in October 1997 to about 30 percent in April 1999.

Japanese agencies also lowered their ratings of Japanese corporate issuers - despite the fact that these agencies generally assign higher ratings to Japanese companies than do Moody's, Standard and Poor's, and other U.S. agencies. ${ }^{5}$ The share of companies rated AAA or AA by Japanese agencies declined from about 32 percent in

The share of companies rated $A A A$ or $A A$ by Japanese agencies declined from about 32 percent in the fall of 1997 to less than 19 percent in the spring of 1999.

the fall of 1997 to less than 19 percent in the spring of 1999 (Chart 1). ${ }^{6}$ In addition, the prevalence of noninvestment-grade ratings increased significantly: In October 1997, two of the nonfinancial firms rated by Japanese agencies had less than investment-grade status; by April 1999, that number had risen to thirteen firms.
As credit ratings fell, the gap between the yields on corporate and government bonds widened. Chart 2 presents movements in the mean and median spreads between the yields on Japanese corporate bonds and Japanese government bonds of the same maturity. ${ }^{7}$ As the chart indicates, the mean spread declined from 68 basis points to 66 basis points between April and October 1997. By April 1998, however, the mean spread had increased to 120 basis points. The rise in the mean spread continued through 1998 and reached a two-year high of 161 basis points on April 1, 1999.

\section{The Credit Curve and the Rise in Spreads}

Japan's 1997-98 recession and the resulting decline in corporate creditworthiness undoubtedly played a role in the increase in yield spreads. But the drop in credit ratings - a key measure of creditworthiness - can explain only a part of the rise in yield spreads in Japan's corporate bond market. When we control for the decline in ratings, the market still quotes much higher yields for Japanese corporate bonds than in the past.

Chart 3 plots the spreads on Japanese corporate bonds by rating level from fall 1997 to spring 1999. From October 1997 to April 1998, the mean spreads for Japanese corporate bonds at every rating level widened significantly, ranging from 10 basis points for AA-rated bonds to 100 basis points for B-rated bonds. The fact

\section{Chart 1 \\ The Decline in Credit Quality: Percentage of Japanese Corporate Issuers in Different Rating Categories, October 1997 and April 1999}

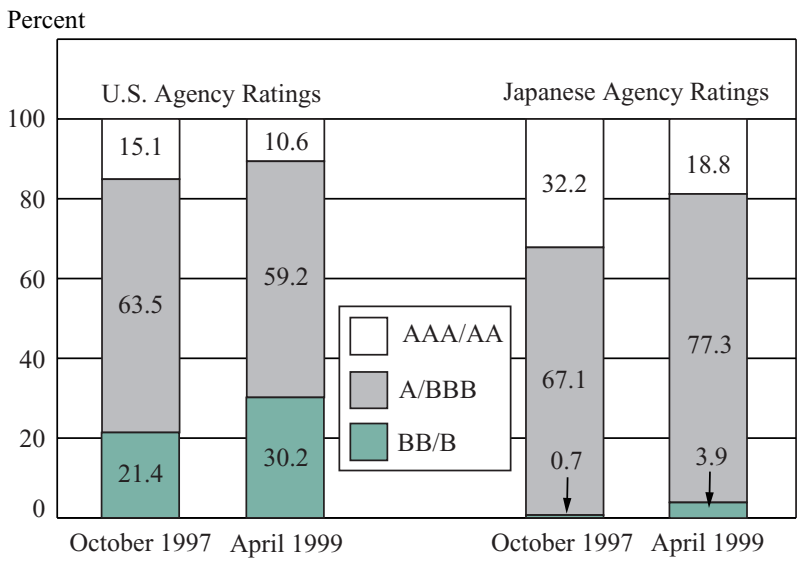

Source: IBJ Securities.

Notes: The number of firms for which Japanese agency ratings were obtained was 283 in October 1997 (126 for U.S. agency ratings) and 335 in April 1999 (169 for U.S. agency ratings). Mean ratings are calculated separately using Japanese agency ratings and U.S. agency ratings. If the mean falls between rating categories, the lower rating is taken. 
that the increases occurred within and across levels provides strong evidence that the widening of spreads was not simply a response to agency downgrades.

Also revealing is the change in the distribution of bond spreads between April 1998 and April 1999. During this period, the rise in spreads on bonds rated A leveled off while the spreads on lower rated bonds continued to climb another 100 to 250 basis points (Chart 3 ). Significantly, this steepening of the credit curve took place at a time when the risks facing major Japanese

\section{When we control for the decline}

in ratings, the market still quotes much

higher yields for Japanese corporate

bonds than in the past.

banks were subsiding, and the quoted rates on the overseas dollar deposits of these banks were reverting to their pre-crisis levels. ${ }^{8}$ The upsurge in spreads on lower rated bonds when the financial sector was regaining some stability suggests that the pricing of Japanese

\section{Chart 2}

\section{Mean and Median Spreads of Japanese Corporate Bond Issuers}

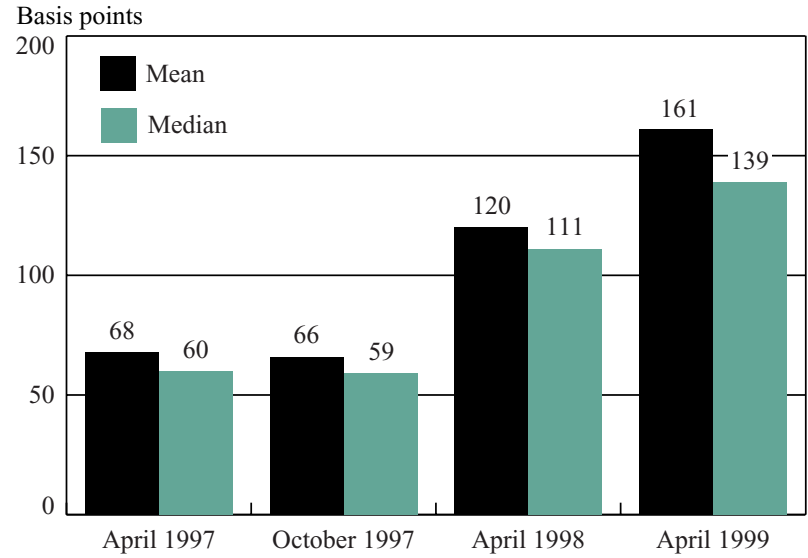

Source: Japan Securities Dealers Association.

Notes: A spread is defined as the yield to maturity of an issuer's outstanding bond minus the yield to maturity of a Japanese government bond of the same maturity. The number of issuers for which spread data were obtained was 200 in April 1997 and October 1997, 253 in April 1998, and 298 in April 1999. The mean spread is the average spread for all issuers in the sample; the median spread is the spread at the midpoint of the sample distribution. The mean and median spreads are calculated on an issuer basis in each time period: that is, only one observation per firm is taken. In the case of multiple bonds outstanding for any one issuer, the bond with the maturity closest to five years is taken. corporate bonds had become increasingly independent of banking conditions.

The shift in the distribution of spreads may be a sign that a "credit culture" is taking root in Japan. Until the mid-1990s, Japanese investors had relatively little need to distinguish corporate issues by credit risk because bondholders were protected by implicit guarantees and bonds rarely went into default. However, the higher spreads

\section{The shift in the distribution of spreads may be a sign that a "credit culture" is taking root in Japan.}

observed on lower grade bonds in 1998 and 1999 suggest that implicit guarantees are effectively disappearing and that the market is becoming more sensitive to the riskiness of individual issuers. ${ }^{9}$ If credit risk has indeed become more important in the market valuation of bond issues, this development would represent a fundamental change in the structure of Japan's corporate bond market.

One might argue, of course, that the shift in spreads is simply evidence that ratings are more stable than spreads. Credit rating agencies rarely change their ratings on the

\section{Chart 3 \\ The Credit Curve: The Spread between the Yields on Japanese Corporate and Government Bonds, by Credit Rating \\ October 1997 to April 1999}

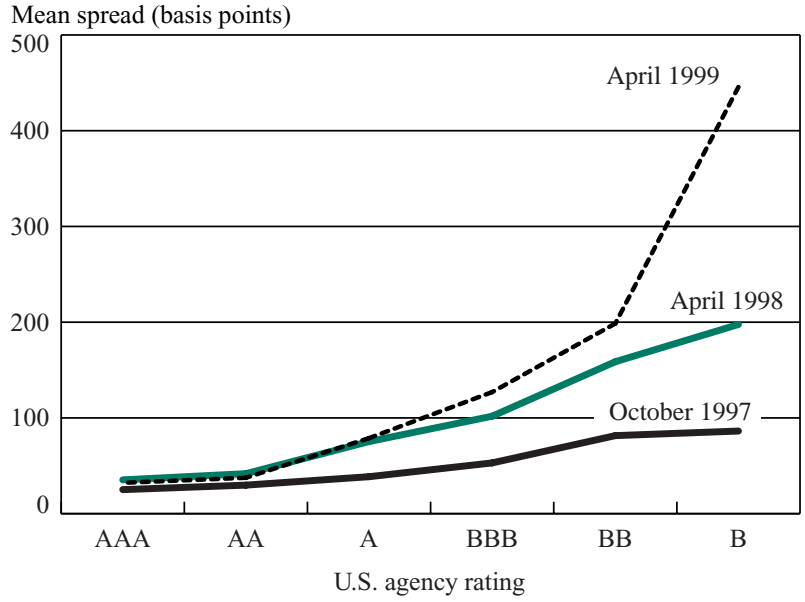

Sources: Japan Securities Dealers Association; IBJ Securities. Note: The number of firms for which both spread and U.S. ratings data were taken was 119 for October 1997, 135 for April 1998, and 165 for April 1999. 
basis of cyclical considerations alone - a fact that may explain why the frequency of defaults within rating categories rises in recessions (Fons 1991). As a result, an increase in spreads at each rating level - and especially at lower grades - is to be expected when a recession deepens, as it did in Japan in 1997 and 1998, and does not necessarily imply structural change in the bond market.

\section{Evidence of Structural Changes in Japan's Corporate Bond Market}

To explore whether the pricing of corporate bonds does reflect fundamental changes in the structure of the market, we first look at the correlation between bond market price quotes and credit ratings in October 1997 and April 1999. If increased spreads simply reflect the stability of ratings relative to market movements, we would not necessarily expect to see an increase in the correlation between spreads and ratings over this period. Table 2 reports both the ordinary and the rank-

\section{[Our] results support the view that the value of membership in a keiretsu has declined in recent years.}

order correlation of logged spreads with the ratings of the two agencies that assign the highest number of publicly available ratings in Japan-Japan Rating and Investment Information (R\&I) and Moody's Investors Service. ${ }^{10}$

In October 1997, the ordinary correlation statistics were .87 (Moody's) and .91 (R\&I). By April 1999, these figures had increased to .92 and .95 , respectively, indicating a tighter relationship between spreads and ratings. The rank-order correlation statistics also increased for both sets of ratings. ${ }^{11}$ These findings suggest that the recent pricing pattern of bonds is more than a cyclical phenomenon and that pricing is now more closely tied to credit risk as measured by credit ratings.

\section{Table 2}

The Relationship between Ratings and Logged Spreads

\begin{tabular}{lcccc} 
& \multicolumn{2}{c}{$\begin{array}{c}\text { Moody's Ratings } \\
(115 \text { Firms })\end{array}$} & \multicolumn{2}{c}{$\begin{array}{c}\text { R\&I Ratings } \\
\text { (188 Firms) }\end{array}$} \\
\cline { 2 - 5 } & $\begin{array}{c}\text { Ordinary } \\
\text { Correlation }\end{array}$ & $\begin{array}{c}\text { Rank-Order } \\
\text { Correlation }\end{array}$ & $\begin{array}{c}\text { Ordinary } \\
\text { Correlation }\end{array}$ & $\begin{array}{c}\text { Rank-Order } \\
\text { Correlation }\end{array}$ \\
\hline October 1997 & .87 & .88 & .91 & .90 \\
April 1999 & .92 & .91 & .95 & .93 \\
\hline
\end{tabular}

Sources: Japan Securities Dealers Association; Bank of Japan; IBJ Securities.

\begin{tabular}{|c|c|c|c|c|}
\hline & $\begin{array}{r}\text { Keire } \\
(83 \\
\end{array}$ & $\begin{array}{l}\text { Firms } \\
\text { rms) }\end{array}$ & $\begin{array}{r}\text { Non-Kei } \\
\quad(145 \\
\end{array}$ & $\begin{array}{l}\text { tsu Firms } \\
\text { irms) }\end{array}$ \\
\hline & Mean & Median & Mean & Median \\
\hline October 1997 & 59 & 56 & 70 & 63 \\
\hline April 1999 & 183 & 156 & 163 & 153 \\
\hline $\begin{array}{l}\text { Change from } \\
\text { October } 1997 \text { to April } 1999 \\
\text { (percent) }\end{array}$ & $\begin{array}{c}124 \\
(208)\end{array}$ & $\begin{array}{c}100 \\
(162)\end{array}$ & $\begin{array}{c}93 \\
\text { (133) }\end{array}$ & $\begin{array}{c}86 \\
(115)\end{array}$ \\
\hline
\end{tabular}

Sources: Japan Securities Dealers Association; Bank of Japan; IBJ Securities; Dodwell Marketing Consultants.

Note: The mean spread is the average spread for all issuers in the sample; the median spread is the spread at the midpoint of the sample distribution.

As another test of structural change, we look at the yield spreads for Japan's keiretsu firms. In the past, when a member of a keiretsu was in financial trouble, the keiretsu's main bank typically bought up the firm's outstanding bonds at full face value (Aoki and Patrick 1994; Campbell and Hamao 1994). This practice may in part explain why there have been only a few defaults on public rated bonds in Japan to date. ${ }^{12}$ Given Japan's recent financial crisis and the rise in bankruptcies, however, investors may place less value on the implicit guarantees typically associated with keiretsu membership than they did in the past. A decrease in the perceived value of keiretsu membership would likely cause the riskiness of bonds issued by keiretsu firms to rise relative to the riskiness of bonds issued by non-keiretsu firms.

We identify keiretsu members in our sample of bond issues and compare the pattern of spreads for these firms and non-keiretsu firms (Table 3). ${ }^{13}$ As shown in the table, the mean spread for keiretsu firms was 59 basis points in October 1997, more than 10 basis points lower than the mean spread for non-keiretsu firms. By April 1999, however, the mean spread for keiretsu firms had more than tripled, reaching 183 basis points, and both the mean and median spreads exceeded those of the non-keiretsu firms. Test statistics indicate that the mean and median changes in spreads were significantly greater for keiretsu firms in both absolute and percentage terms. ${ }^{14}$ These results support the view that the value of membership in a keiretsu has declined in recent years.

\section{Conclusion}

The pricing of corporate debt in Japan has undergone some major changes in the past few years. Between the fall of 1997 and the spring of 1999, quoted spreads for bonds at every rating level rose significantly. Moreover, although the quoted rates on the overseas dollar deposits 
of major Japanese banks returned to pre-crisis levels by April 1999, credit spreads on corporate debt in Japan remained far above earlier levels. In particular, the spreads on the debt of lower rated corporate bonds showed a dramatic rise from spring 1998 to spring 1999.

The movement of yield spreads suggests that structural changes are under way in the corporate bond market. First, the rise in spreads has been accompanied by a heightened correlation between spreads and credit ratings. This correlation reflects an increasing emphasis on credit risk-historically, a relatively minor factor in the pricing of Japanese bonds. Second, the increase in spreads since the fall of 1997 has been greater for keiretsu firms than for other firms. The uneven rise in spreads implies that the prospect of financial backing from affiliated keiretsu firms may no longer hold as much weight among investors as it did in the past. These ongoing structural changes could transform Japan's corporate bond market further in the years ahead.

\section{Notes}

1. Many issuers report being motivated by a need to secure a source of long-term financing other than bank loans (Standard and Poor's 1999). For a discussion of the broad trends in the use of these alternative sources of financing, see Hoshi and Kashyap (1999).

2. A body of empirical evidence suggests that membership in a keiretsu may reduce the costs of financial distress (Hoshi, Kashyap, and Scharfstein 1990).

3. The rate of public firm bankruptcies in Japan has also accelerated. Twenty public firms went bankrupt in 1997-98 alone-a greater number than in the previous sixteen years combined.

4. To calculate a U.S. rating of Japanese corporate bonds, we average the ratings of Moody's and Standard and Poor's. If the average falls between rating categories, the lower rating is used.

5. For a discussion of the differences between Japanese and U.S. agency ratings, see Packer and Reynolds (1997).

6. Japanese ratings for fall 1997 are calculated as the average of the October ratings assigned by Japan Bond Rating Institute, Nippon Investors Service, and Japan Credit Rating Agency. Because the Japan Bond Rating Institute and Nippon Investors Service merged to form Japan Rating and Investment Information (R\&I) in April 1998, Japanese ratings for spring 1999 are calculated as the average of the ratings assigned by R\&I and Japan Credit Rating Agency. If the average falls between rating categories, the lower rating is used.

7. The mean spread is the average spread for all issuers in the sample; the median spread is the spread at the midpoint of the sample distribution. Spreads and other data are from the Japan Securities Dealers Association (JSDA). In April 1997, the JSDA greatly increased the release of over-the-counter standard bond quotations. Securities companies surveyed by JSDA supply quotes for transactions with a face value of approximately 500 million yen; averages of these quotes are published daily and are now available on-line from news sources such as Bloomberg. All spread calculations include one observation per firm. In the case of multiple bonds outstanding, we take the bond with the maturity closest to five years. As in Hamao and Hoshi (forthcoming), six firms in the construction sector that had outstanding bonds with extremely discounted prices throughout the sample period are dropped from the sample. For discussion of sectoral distinctions and trends in the pricing of Japanese corporate bonds, see Ieda and Ohba (1998) and Miyanoya (1998).

8. The rapid rise in spreads between October 1997 and April 1998 was paralleled by a rise in the "Japan premium," or the difference between the mean of the deposit rates that Japanese banks reported paying in international interbank markets and the mean reported by other banks to the British Bankers Association. However, after the adoption of new bank reforms in Japan, the passage of recapitalization legislation, and the nationalization of two major banks, the premium returned to pre-crisis levels by April 1999.

9. See Moody's Investors Service (1998) for a discussion of the increased credit sensitivity of Japanese domestic investors.

10. The ordinary correlation coefficient, which can vary between -1 and 1 , is a measure of the strength of a linear relationship between two variables. The rank-order correlation is calculated using the rank orderings of two variables instead of their actual values. For the calculation of all correlation coefficients, the ratings variable is transformed as follows: $\mathrm{AAA}(\mathrm{Aaa})=1, \mathrm{AA}+(\mathrm{Aa} 1)=2$, $\ldots, \mathrm{B}-(\mathrm{B} 3)=16$; thus, a positive correlation coefficient implies that higher spreads are associated with lower ratings. Because the relationship of the ratings variable and spreads is nonlinear, we use logged spreads. For a fuller discussion of the relationship between ratings and spreads, see Cantor and Packer (1996).

11. Three of the four changes in correlation are statistically significant at standard significance levels. The p-values for the z-statistics for testing the null hypothesis of no increase in ordinary correlation between periods is .001 (R\&I ratings) and .021 (Moody's ratings). The parallel p-values for the z-statistics relating to the rank-order correlation are .031 (R\&I ratings) and .115 (Moody's ratings). The test statistic is described in Dunn and Clark (1974).

12. The three companies that defaulted on rated public debt in Japan in the postwar era did so in 1996 and 1997 (Japan Center for International Finance 1999). Although the low rate of default stemmed in part from the implicit guarantees accorded keiretsu members, it also reflected the fact that only a limited subset of the listed companies had issued public bonds, and most of these were relatively low credit risks.

13. The keiretsu firms are firms that are identified by Dodwell Marketing Consultants (1996) as having a strong affiliation with one of the eight horizontal keiretsu (Mitsubishi, Mitsui, Sumitomo, Fuyo, DKB, Sanwa, Tokai, and IBJ).

14. The p-value for the Wilcoxon signed rank statistic for testing the null hypothesis of no difference in the median change in spread between keiretsu and non-keiretsu firms is .034; the p-value for testing the null hypothesis of no difference in the median percentage change in spread is .000 . 


\section{References}

Aoki, Masahiko, and Hugh Patrick, eds. 1994. The Japanese Main Bank System: Its Relevance for Developing and Transforming Economies. Oxford: Oxford University Press.

Campbell, John, and Yasushi Hamao. 1994. "Changing Patterns of Corporate Financing and the Main Bank System in Japan." In Masahiko Aoki and Hugh Patrick, eds., The Japanese Main Bank System: Its Relevance for Developing and Transforming Economies, 325-49. Oxford: Oxford University Press.

Cantor, Richard, and Frank Packer. 1996. "The Determinants and Impact of Sovereign Credit Ratings." Federal Reserve Bank of New York Economic Policy Review 2, no. 2: 37-53.

Dodwell Marketing Consultants. 1996. Industrial Groupings in Japan.

Dunn, Olive J., and Virginia Clark. 1974. Applied Statistics: Analysis of Variance and Regression. New York: John Wiley.

Fons, Jerome. 1991. An Approach to Forecasting Default Rates. Moody's Investors Service.

Hamao, Yasushi, and Takeo Hoshi. Forthcoming. "Bank Underwriting of Corporate Bonds: Evidence from Japan after 1994." In Masahiko Aoki and Gary Saxonhouse, eds., Finance, Governance, and Competition in Japan. Oxford: Oxford University Press.

Hoshi, Takeo, and Anil Kashyap. 1999. "The Japanese Banking Crisis: Where Did It Come From and How Will It End?" NBER Macroeconomics Annual.
Hoshi, Takeo, Anil Kashyap, and David Scharfstein. 1990. "The Role of Banks in Reducing the Costs of Financial Distress in Japan." Journal of Financial Economics 27, no. 1: 67-88.

Ieda, Akira, and Toshikazu Ohba. 1998. "Recent Trends in the Spread over Libor on the Domestic Straight Bond Trading Market in Japan." Monetary and Economic Studies 16, no. 2: 113-28.

Japan Center for International Finance. 1999. Characteristics and Appraisal of Major Rating Companies (1999)_Focusing on Ratings in Japan and Asia, April.

Miyanoya, Atsushi. 1998. "Price Discovery Function in Japan's Corporate Bond Market: An Event Study of the Recent Fall 1997 Crisis.” Working paper, Bank of Japan.

Moody's Investors Service. 1998. "Decline and Fall of the 'Joint Support' Regime in Japan's Domestic Bond Market.” Special Comment, February.

Packer, Frank, and Elizabeth Reynolds. 1997. "The Samurai Bond Market.” Federal Reserve Bank of New York Current Issues in Economics and Finance 3, no. 8.

Standard and Poor's. 1999. "Japan: Credit Risk Takes Hold in the World's Second-Largest Economy." Standard and Poor's Credit Week, March 24.

\section{About the Author}

Frank Packer is a senior economist in the Capital Markets Function of the Research and Market Analysis Group.

The views expressed in this article are those of the author and do not necessarily reflect the position of the Federal Reserve Bank of New York or the Federal Reserve System.

Current Issues in Economics and Finance is published by the Research and Market Analysis Group of the Federal Reserve Bank of New York. Dorothy Meadow Sobol is the editor.

Editorial Staff: Valerie LaPorte, Mike De Mott, Elizabeth Miranda

Production: Carol Perlmutter, Lingya Dubinsky, Jane Urry

Subscriptions to Current Issues are free. Write to the Public Information Department, Federal Reserve Bank of New York, 33 Liberty Street, New York, N.Y. 10045-0001, or call 212-720-6134. Current Issues is also available at the Research and Market Analysis Group's web site: http:/www.ny.frb.org/rmaghome/curr_iss/1999.html.

\section{Get New Publications Quickly via Electronic Alert}

By subscribing to our free Electronic Alert Service, you can automatically receive e-mail notifications when new publications are posted at the Research and Market Analysis Group's web site. You can then go directly to the site and download the materials. Please visit http://www.ny.frb.org/rmaghome for details. 